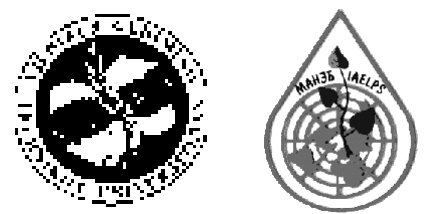

\title{
JOURNAL OF ENVIRONMENTAL ENGINEERING AND LANDSCAPE MANAGEMENT
}

http:/www.vtu.lt/english/editions

2004, Vol XII, No 4, 138-145

\section{HIGH-TEMPERATURE DECONTAMINATION AND UTILIZATION OF PHOSPHOGYPSUM}

\author{
Algimantas Kazragis \\ Dept of Chemistry and Bioengineering, Vilnius Gediminas Technical University, \\ Sauletekio al. 11, LT-10223 Vilnius-40, Lithuania. \\ E-mail: chemkat@fm.vtu.lt
}

Received 25 Jun 2004; accepted 27 Sept 2004

\begin{abstract}
Waste piles of phosphogypsum formed from deposits of phosphoric acid production by-product loom near the city of Kedainiai in the center of Lithuania. Every year about 250 thousand tons of this by-product were gathered when the plant was in full operation. At present, about 13 to 15 million tons of phosphogypsum have accumulated which is mainly gypsum dihydrate - (95-98) \%, however, contaminated with phosphoric and fluoric acids as well as with other hazardous admixtures what makes this raw material ecologically harmful and also hampers the use of phosphogypsum instead of natural gypsum for the production of binding materials. These materials pollute the environment. Phosphogypsum can be „deacidified“ with lime and then treated as normal natural gypsum to obtain hemi hydrate gypsum. However, good-quality binding materials were not obtained in this case. Heating of phosphogypsum up to a temperature of $600{ }^{\circ} \mathrm{C}$ provides for the decomposition and elimination of binding obstruction admixtures. Heating to $1000^{\circ} \mathrm{C}$ and higher temperatures causes the decomposition of the former with the formation of an activator in anhydrite lime and thus anhydrite cement. In general, the utilization of this environmentally harmful waste and the binding of toxic pollutants can contribute to the solution of environmental problems in the central region of Lithuania.
\end{abstract}

Keywords: detoxication, utilization, phosphogypsum, kaolin, high-temperature burning, binding materials.

\section{Introduction}

As various branches of industry - metallurgy, energy, construction materials, food and others as well as transport develop more and more harmful gases, such as $\mathrm{CO}_{2}, \mathrm{CO}$, $\mathrm{SO}_{2}, \mathrm{NO}, \mathrm{NO}_{2}, \mathrm{HCl}, \mathrm{HF}$, not fully combusted hydrocarbons, also inorganic and volitile organic acids, organic solvents, the constituent parts of varnishes and paints vapours and gases are emitted into the atmosphere.

Lithuanian researchers, including those from Vilnius Gediminas Technical University, Department of Environmental Protection, have conducted many investigations over the past years to evaluate various inert and toxic pollutant concentrations in the air [1-8], atmospheric precipitation [9] wastewater, in ponds and natural water basins and also in the soil [10-15]. All these data were compared by using instrumental methods, critically evaluated and a new generation of biofilters were developed which recommended themselves very well during further investigations [16-24].

Mineral fertilizer production is one of the branches of the chemical industry which emits hazardous materials into the environment, which are toxic to humans, fauna and flora. In 1963-1973 not far from the city of
Kedainiai in the center of Lithuania four sulphuric acid production lines were put into operation as well as those for the production of conventional and granulated superphosphate, aluminum fluoride, phosphoric acid, amofose and other fertilizer mixtures.

The main technological by-product produced at the Kèdainiai Chemical Plant (later Joint-Stock Company „Lifosa“) was phosphogypsum. It is formed during the manufacture of phosphoric acid by reacting the mineral apatite brought from Khibini region, Russia, with sulphuric acid according to the following reaction:

$$
\begin{aligned}
& 3 \mathrm{Ca}_{3}\left(\mathrm{PO}_{4}\right)_{2} \cdot \mathrm{CaF}_{2}+10 \mathrm{H}_{2} \mathrm{SO}_{4}+20 \mathrm{H}_{2} \mathrm{O}= \\
& 10\left[\mathrm{CaSO}_{4} \cdot 2 \mathrm{H}_{2} \mathrm{O}\right]+6 \mathrm{H}_{3} \mathrm{PO}_{4}+2 \mathrm{HF} .
\end{aligned}
$$

Phosphogypsum is made up of (95-98) \% of gypsum dihydrate $\mathrm{CaSO}_{4} \cdot 2 \mathrm{H}_{2} \mathrm{O}$. Due to various admixtures, $\mathrm{CaCl}_{2}, \mathrm{SiO}_{2}, \mathrm{CaCO}_{3}, \mathrm{Al}_{2} \mathrm{O}_{3}, \mathrm{Fe}_{2} \mathrm{O}_{3}$ which are present in apatite reaction with $\mathrm{H}_{2} \mathrm{SO}_{4}$ and $\mathrm{H}_{3} \mathrm{PO}_{4}$, a number of other compounds are formed like: $\mathrm{Ca}\left(\mathrm{H}_{2} \mathrm{PO}_{4}\right)_{2} \cdot \mathrm{H}_{2} \mathrm{O}, \mathrm{HF}$, $\mathrm{H}_{2} \mathrm{SiF}_{6}, \mathrm{HCl}, \mathrm{Ca}_{3}\left(\mathrm{PO}_{4}\right)_{2}, \mathrm{AlPO}_{4}, \mathrm{FePO}_{4}, \mathrm{CaF}_{2}, \mathrm{AlF}_{3}$, $\mathrm{FeF}_{3}$, also small quantaties of apatite, magnesium, lanthanide compounds and various amounts of absorbed water are present. 


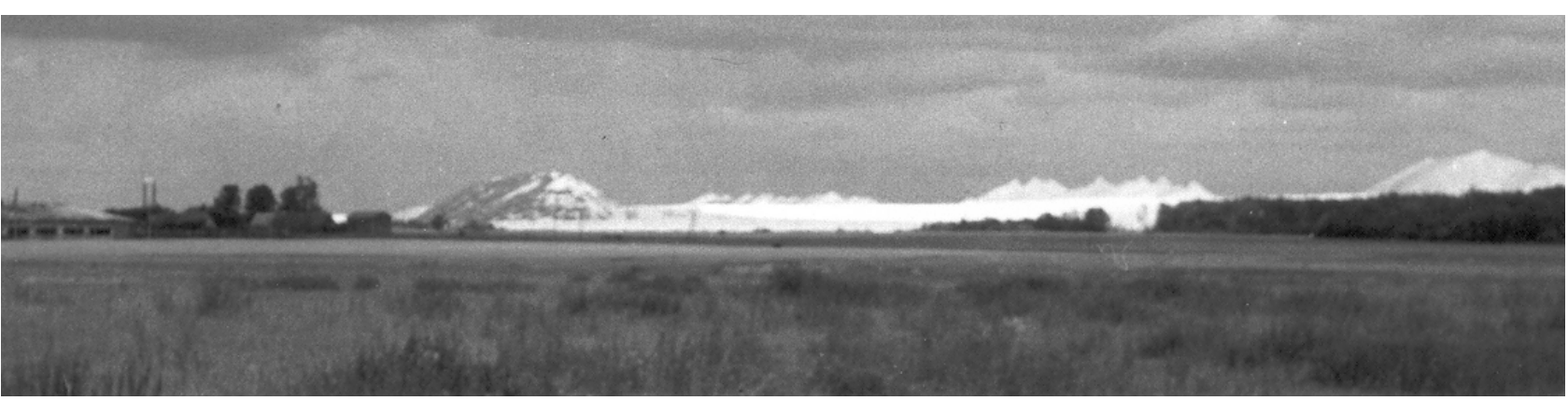

Fig 1. Phosphogypsum waste piles near the city of Kèdainiai (author's photo)

After several decades of production thousands of tons of phosphogypsum have accumulated in waste piles not far from Kèdainiai.

Atmospheric precipitation has leached out many hazardous materials from these waste piles of phosphogypsum which entered the soil, then the surface water basins and ground water. Due to the influence of these pollutants surrounding trees looked like those in autumn with very little foliage. A little later, when air filters were installed in the production lines, the emissions into the atmosphere decreased.

Hydrogen fluoride (HF) is a colourless, volitile gas with a maximum admissible concentration (MAC) in the air of $0,5 \mathrm{mg} / \mathrm{m}^{3}$. In the case of phosphoric acid MAC is a little higher and equal to $1 \mathrm{mg} / \mathrm{m}^{3}$. So we can conclude that these substances are rather toxic, and their presence in phosphogypsum as well as during production and in waste piles is hazardous to humans, the environment and especially to vegetation.

The presence of acidic admixtures $\mathrm{H}_{3} \mathrm{PO}_{4}, \mathrm{HF}$, $\mathrm{H}_{2} \mathrm{SiF}_{6}$ does not allow to reuse this by-product for structural gypsum production without any reprocessing.

The methods of low-temperature reprocessing evolve deacidification (neutralization) by lime (a slurry in water works best) at ambient temperatures. During the process $\mathrm{Ca}(\mathrm{OH})_{2}$ neutralizes acidic admixtures, and insoluble precipitates are formed:

$$
\begin{aligned}
& 3 \mathrm{Ca}(\mathrm{OH})_{2}+2 \mathrm{H}_{3} \mathrm{PO}_{4}=\mathrm{Ca}_{3}\left(\mathrm{PO}_{4}\right)_{2} \times \mathrm{mH}_{2} \mathrm{O}+ \\
& (6-\mathrm{m}) \mathrm{H}_{2} \mathrm{O} .
\end{aligned}
$$

The method of high-temperature phosphogypsum reprocessing is based on phosphogypsum thermal treatment after which: 1) dihydrate gypsum transforms into anhydrite, and $\mathrm{CaO}$ is formed little by little; 2) hazardous admixtures $\left(\mathrm{H}_{3} \mathrm{PO}_{4} \cdot \mathrm{H}_{2} \mathrm{SiF}_{6}, \mathrm{HF}\right)$ decompose and evaporate.

The following transformations occur:

1) dihydrate gypsum $(120-160)^{\circ} \mathrm{C}$ transforms to aor b-hemi hydrate, while at $(170-220){ }^{\circ} \mathrm{C} \alpha$ - or $\beta$ - soluble anhydrite, the latter at $>400{ }^{\circ} \mathrm{C}$ changes to an insoluble form which without an activator (e $\mathrm{g} \mathrm{CaO}$ ) does not harden, but at $800{ }^{\circ} \mathrm{C}$ transforms into hydraulic gypsum, possessing enough $\mathrm{CaO}$ for binding to occur:

$$
(\mathrm{n}+1) \mathrm{CaSO}_{4}=n \mathrm{CaSO}_{4}+\mathrm{CaO}+\mathrm{SO}_{2}+0,5 \mathrm{O}_{2} \text {. }
$$

It is inexpediant to heat the substance during production of anhydrite binding materials to full decomposition because over-heated anhydrite is obtained. That is why it is enough to continue heating until, for example, $5 \%$ of active $\mathrm{CaO}$ is formed.

Phosphogypsum reprocessing and usage possibilities were investigated since 1964 (Kaunas Polytechnical Institute, J. Kapačiauskas) and many other researchers from Kaunas Polytechnical Institute, Institute of Thermal Insulation as well as Institute of Architecture and Construction, whose names should be mentioned (in an alphabetical order): Andriušienė J., Bačauskienė M., Česnienè J., Kaminskas A., Kaziliūnas A., Leškevičienė V., Mandeikytė N., Martusevičius M., Nizevičienè D., Palubeckienė V., Rakaitis J., Sasnauskas K., Stonys S., Urbonas Z., Valančius Z., Vektaris B.

The main publication concerning this period are given in references [22-30].

Joint-Stock Company „Palemono keramika“ during the period 1989-1992 and in 1997 manufactured a novel anhydrite cement composition according to the technology developed by Institute of Architecture and Construction [23]. This material was produced from the following raw materials: JSC „Lifosa“ (Kèdainiai) dihydrate non-acidic phosphogypsum $(\mathrm{pH}=9,8-9,3)-(79,0-$ 79,5) \%; Krūnas deposit clay $-16 \%$; neutralized JSC „Ekranas“ (Panevėžys) glass slime (kinescope glass polishing waste) containing $\mathrm{SiO}_{2}$ and $\mathrm{R}_{2} \mathrm{O}-4 \% ; \mathrm{Ca}(\mathrm{OH})_{2}$ from JSC ,Ventos SM“-(0,5-1,0) \%; water. Here phosphogypsum was neutralized with slaked lime until $\mathrm{pH}=6,5-9,5$ was reached, then clay and glass slime was introduced, water was added and the obtained slip was burnt in a rotary kiln at $(850-900){ }^{\circ} \mathrm{C}$. The obtained granulate had the following chemical composition: $\mathrm{CaO}-$ (25-33) \%; $\mathrm{SO}_{3}-(27-41) \%, \mathrm{R}_{2} \mathrm{O}-(9,15-9,35) \%$, $\mathrm{P}_{2} \mathrm{O}_{5}-(0,52-0,75) \%, \mathrm{~F}-(0,03-0,06) \% ; \mathrm{SiO}_{2}$ and insoluble part-(15-32) \%. In such a way the anhydrite part makes up (46-70) \%. The milled granulate possesses the following physico-mechanical properties: setting of binder - (40-135) min.; binding end - (135-230) min., flexural strength: after 3 days $<2 \mathrm{MPa}$, after 28 days (34,5) $\mathrm{MPa}$; compressive strength: after 3 days (5-7) $\mathrm{MPa}$, after 28 days (16-30) $\mathrm{MPa}$.

Unfortunately, very little attention was paid to hightemperature reactions of phosphogypsum containing $\mathrm{CaO}$ 
with acidic oxide $\mathrm{SiO}_{2}$ (e g kaolin). Meanwhile, the $\mathrm{CaO}-$ $\mathrm{SiO}_{2}$ interaction can give dicalcium silicates, also tricalcium silicates with distinguished binding properties.

The aim of this investigation was to examine the materials binding possibility and properties obtained from phosphogypsum and kaolin by heating then up to $1200^{\circ} \mathrm{C}$.

Also, the hazardous materials present in phosphogypsum waste piles are constantly leached out by the atmospheric precipitation into the environment and pollute the soil. That is why investigations concerning the utilization of harmful waste into useful binding materials will contribute to the solution of environmental problems of the central region of Lithuania.

\section{Experimental investigation}

The following materials were used in the experiments.

Phosphogypsum. The average chemical composition, \%: $\mathrm{Ca}^{2+} 17,05 ; \mathrm{SO}_{4}{ }^{2-} 40,18 ; \mathrm{PO}_{4}{ }^{3-} 1,16 ; \mathrm{F}^{-}$0,11; $\mathrm{SiO}_{2} \quad 0,33 ; \mathrm{Fe}^{3+} 0,002 ; \mathrm{H}_{2} \mathrm{O} 40,72 ; \mathrm{pH}=2,47$. If we express the composition in moles then we obtain the following: $\mathrm{Ca}^{2+} 0,426$; $\mathrm{SO}_{4}{ }^{2-} 0,419 ; \mathrm{PO}_{4}{ }^{3-} 0,01 ; \mathrm{F}^{-} 0,006$; $\mathrm{SiO}_{2}$ 0,005; $\mathrm{H}_{2} \mathrm{O}$ 2.26. From here follows that we get the following molar composition: $\mathrm{CaSO}_{4} \times 2 \mathrm{H}_{2} \mathrm{O}-$ 1 mole; $\mathrm{Ca}$ in other materials (phosphate, fluoride, etc.) 0-0,016 mole; absorbtion water -3,36 mole.

To evapourate absorbed water phosphogypsum was heated in a drying kiln at $105^{\circ} \mathrm{C}$ for 2 days (till constant weight).

Kaolin. Kaolin used in the experiments was obtained from a laboratory in the Department of Geotechnical Engineering of VGTU. The dried material had the following chemical composition: $(38,5-39,2) \%$ $\mathrm{Al}_{2} \mathrm{O}_{3}$ and $(45,4-46,3) \% \mathrm{SiO}_{2}$, which is approximately close to the kaolinite formula $\mathrm{Al}_{2} \mathrm{O}_{3} \cdot 2 \mathrm{SiO}_{2} \cdot 2 \mathrm{H}_{2} \mathrm{O}$. During the experiments the material was ground and dried additionally.

\section{Testing methods}

- The quantative determination of $\mathrm{CaO}, \mathrm{Al}_{2} \mathrm{O}_{3}$ and $\mathrm{SiO}_{2}$ in the material was conducted according to the methods given in Lithuanian Standard LST EN 196-2-Cement. Testing methods - Parts 2 (Chemical analysis - 13.12). Vilnius LSD publishing house, 1996.

- Burning of the phosphogypsum and kaolin mixture was conducted in a high-temperature furnace ,Thermolyne Furnace $6000^{“}$ (up to $1200{ }^{\circ} \mathrm{C}$ ).
- Experimental thermograms were obtained by using a derivatograph Q-1500.

- X-ray diffraction pattern analysis of heated products was conducted by using the X-ray difractometer DRON-2 (Russia) (Co anode, Fe filter, slits $1: 2: 0,5 \mathrm{~mm}$, the difractometer tube's operating mode: $U=3 \mathrm{kV}, I=10 \mathrm{~mA}$ ).

- Measurements of specimen flexural and compressive strength were conducted by using conventional resistance measurement instruments according to the Lithuanian Standard LST 1346:1995 - Construction Mixtures (Technical requirements) by using $40 \times 40 \times$ $160 \mathrm{~mm}$ dimension prisms.

\section{Results and discussion}

\subsection{Thermodynamic analysis of anhydrite thermal decomposition}

It was demonstrated [27] that we could find the thermal treatment temperature to form necessary $\mathrm{CaO}$ amount in heated anhydrite according to thermodynamic calculations based on the following reaction:

$$
\mathrm{CaSO}_{4}=\mathrm{CaO}+\mathrm{SO}_{2}+0,5 \mathrm{O}_{2}
$$

If we adopt that the general evolved gas pressure during the reaction $P$, atm is equal to $\mathrm{SO}_{2}$ and $\mathrm{O}_{2}$ partial pressure $p$, atm sum, then we get: $\mathrm{P}=$ $p_{\mathrm{SO}_{2}}+0,5 p_{\mathrm{O}_{2}}$ and $P=1,5 p_{\mathrm{SO}_{2}}$ From here we obtain the equilibrium constant $K_{p}=0,385 p^{1,5}$ and $\lg K_{p}=-0,4145+$ $1,51 \mathrm{~g} P$.

When we insert this $\lg \mathrm{K}_{\mathrm{p}}$ value into the Gibb's energy change $\Delta G_{T}^{o}$ dependency on $K_{p}$ equation $\Delta G_{T}^{o}=-4,575 \cdot 10^{-3} \mathrm{~T} \cdot \lg K_{p}$, we obtain: $\lg P=10,112$ $17653 / \mathrm{T}$ and $\mathrm{T}=17653 /(10,112-\lg P)$.

Since the anhydrite $\mathrm{CaO}$ amount (in unit parts) is proportional to $P$, atm, then we find: $T=17653 /(10,11-$ $\lg \mathrm{CaO})$.

Then we find in such a way, e $\mathrm{g}$ to obtain $5 \%$ of free $\mathrm{CaO}$ material, it is necessary to sinter the material at almost $1300^{\circ} \mathrm{C}$ (Table).

\subsection{Decomposition of phosphogypsum admixtures during heating}

Unneutralized phosphogypsum contains besides gypsum: $2 \%$ of apatite; $(1,8-5,7) \%$ of $\mathrm{Ca} ; \mathrm{Al}$ and $\mathrm{Fe}$ phosphates as well as fluorides; $>=1$ (up to 6) $\% \mathrm{H}_{3} \mathrm{PO}_{4}$; $(0,3-10) \% \mathrm{SiO}_{2} ;(7-22) \% \mathrm{H}_{2} \mathrm{O}$ [26].

Amount of $\mathrm{CaO}$ in phosphogypsum depending on temperature

\begin{tabular}{|l|c|c|c|c|c|c|c|c|c|}
\hline $\mathrm{CaO}, \%$ & 0,1 & 1 & 2 & 5 & 10 & 25 & 50 & 75 & 100 \\
\hline $\mathrm{CaO}, \% / 100$ & 0,001 & 0,01 & 0,02 & 0,05 & 0,10 & 0,25 & 0,50 & 0,75 & 1,00 \\
\hline $\mathrm{T},{ }^{\circ} \mathrm{K}$ & 1346 & 1457 & 1494 & 1547 & 1589 & 1648 & 1695 & 1724 & 1746 \\
\hline $\mathrm{t},{ }^{\circ} \mathrm{C}$ & 1073 & 1184 & 1221 & 1274 & 1316 & 1375 & 1422 & 1451 & 1473 \\
\hline
\end{tabular}


Gypsum binding properties are mostly hampered by the presence of $\mathrm{HF}, \mathrm{H}_{3} \mathrm{PO}_{4}$ and $\mathrm{Ca}\left(\mathrm{H}_{2} \mathrm{PO}_{4}\right)_{2} \cdot 2 \mathrm{H}_{2} \mathrm{O}$. Thermal treatment of phosphogypsum decontaminates it.

Hydrogen fluoride is dissolved in moisture present in phosphogypsum, and when it is heated at $>100{ }^{\circ} \mathrm{C}$ temperature, water evaporates.

Phosphoric acid during heating transforms into pyrophosphorous (diphosphoric) acid:

$$
2 \mathrm{H}_{3} \mathrm{PO}_{4}\left(>215{ }^{\circ} \mathrm{C}\right)=\mathrm{H}_{4} \mathrm{P}_{2} \mathrm{O}_{7}+\mathrm{H}_{2} \mathrm{O}
$$

The later polymerisizes into polymetaphosphoric acid:

$(n=3-8): n \mathrm{H}_{4} \mathrm{P}_{2} \mathrm{O}_{7}\left(>300{ }^{\circ} \mathrm{C}\right)=2\left(\mathrm{HPO}_{3}\right)_{\mathrm{n}}+n \mathrm{H}_{2} \mathrm{O}$.

During heating of this compound it evolves $\mathrm{P}_{2} \mathrm{O}_{5}$ vapours:

$$
2\left(\mathrm{HPO}_{3}\right)_{n}=n \mathrm{P}_{2} \mathrm{O}_{5}+n \mathrm{H}_{2} \mathrm{O}
$$

So, in such a way phosphoric acid present in phosphogypsum waste during burning completely decomposes and it evolves as $\mathrm{P}_{2} \mathrm{O}_{5}$ and $\mathrm{H}_{2} \mathrm{O}$.

Calcium dihydrophosphate present in phosphogypsum decomposes [6] as follows:

$$
\begin{aligned}
& \mathrm{Ca}\left(\mathrm{H}_{2} \mathrm{PO}_{4}\right)_{2} \cdot \mathrm{H}_{2} \mathrm{O}\left(100-110{ }^{\circ} \mathrm{C}\right)=\mathrm{Ca}\left(\mathrm{H}_{2} \mathrm{PO}_{4}\right)_{2}+ \\
& \mathrm{H}_{2} \mathrm{O}, \\
& 2 \mathrm{Ca}\left(\mathrm{H}_{2} \mathrm{PO}_{4}\right)_{2}\left(150-200{ }^{\circ} \mathrm{C}\right)=\mathrm{Ca}_{2} \mathrm{P}_{2} \mathrm{O}_{7}+\mathrm{P}_{2} \mathrm{O}_{5}+ \\
& 4 \mathrm{H}_{2} \mathrm{O} .
\end{aligned}
$$

Calcium dihydrophosphate present in phosphogypsum dissociates in the same way as phosphoric acid when phosphogypsum is heated.

- pH-metric analysis of burnt phosphogypsum

Our pH-metric investigations [26] have shown that untreated phosphogypsum saturated solution samples showed an increase in $\mathrm{pH}$ value with an increase in thermal treatment temperature (see values $\mathrm{t}^{\circ} \mathrm{C} / \mathrm{pH}$ ): $105 / 3,02$; 200/3,02; 300/3,80; 400/3,90; 500/4,80; 600/5,78; 650/ 5,$89 ; 700 / 6,04 ; 750 / 6,18 ; 800 / 6,26 ; 900 / 6,32 ; 1000 / 6,44$.

Such a course of $\mathrm{pH}$ value change can be explained by the decomposition of the heated product at different temperatures:

1) At $(100-200){ }^{\circ} \mathrm{C}$ - water is liberated; 2) (200$300){ }^{\circ} \mathrm{C}-$ water evolves from $\mathrm{H}_{3} \mathrm{PO}_{4}$ and $\mathrm{Ca}\left(\mathrm{H}_{2} \mathrm{PO}_{4}\right)_{2}$; 3) $(300-450){ }^{\circ} \mathrm{C}$ the $\mathrm{Ca}\left(\mathrm{H}_{2} \mathrm{PO}_{4}\right)_{2}$ decomposition ends; 4) (450-600) ${ }^{\circ} \mathrm{C}$ diphosphoric and latter polymetaphosphoric acid decomposes with the emission of $\mathrm{P}_{2} \mathrm{O}_{5}$, 5) $\left(>600{ }^{\circ} \mathrm{C}\right)$ - the formation of inactive anhydrite takes place.

Phosphogypsum calcined up to $1000{ }^{\circ} \mathrm{C}$ contains very little amount of admixtures, which practically have no effect on the product's binding properties (compound and melting temperature, ${ }^{\circ} \mathrm{C}$ ): $\mathrm{FeF}_{3}$ 1027; $\mathrm{AlF}_{3}$ 1040; $\mathrm{Ca}_{3} \mathrm{P}_{2} \mathrm{O}_{7}$ 1350; $\mathrm{CaF}_{2} 1403 ; \mathrm{Ca}_{3}\left(\mathrm{PO}_{4}\right)_{2}$ 1670; $\mathrm{SiO}_{2}$ 1728; $\mathrm{AlPO}_{4} 2000$.

\subsection{Binding properties of phosphogypsum sintered up to $1000{ }^{\circ} \mathrm{C}$}

Our experiments [28] have shown that phosphogypsum heated in the temperature range $(600-$ $800){ }^{\circ} \mathrm{C}$ with an addition of $6 \%$ of $\mathrm{Ca}(\mathrm{OH})_{2}$ gave specimens with a flexural strength $(0,3-2,2) \mathrm{MPa}$ and compressive strength $(0,4-1,2) \mathrm{MPa}$.

Materials prepared in these conditions distinguish themselves by low anhydrite cement strength properties and can be used for conventional purposes.

\subsection{Preparation possibilities of binding materials from high-temperature interaction of phosphogypsum and kaolin}

Partial decomposition of $\mathrm{CaSO}_{4}$ begins at $960{ }^{\circ} \mathrm{C}$ in phosphogypsum during its burning and is associated with the formation of $\mathrm{CaO}$ (in the presence of $\mathrm{SiO}_{2}$ or $\mathrm{Al}_{2} \mathrm{O}_{3}$, this decomposition begins at lower temperatures).

The calcination of kaolin (white clay) which is mainly composed of kaolinite $\mathrm{Al}_{4}\left[\mathrm{Si}_{4} \mathrm{O}_{10}\right](\mathrm{OH})_{8}$ (in the oxide expression form $-\mathrm{Al}_{2} \mathrm{O}_{3} \cdot 2 \mathrm{SiO}_{2} \cdot 2 \mathrm{H}_{2} \mathrm{O}$ and in the silicate chemistry accepted form $\left.-\mathrm{AS}_{2} \mathrm{H}_{2}\right),(500-600){ }^{\circ} \mathrm{C}$ gives metakaolinite as the resulting product $\mathrm{AS}_{2}$; (10001200) ${ }^{\circ} \mathrm{C}$ - sillimanite AS and (1200-1500) ${ }^{\circ} \mathrm{C}$ - mullite $\mathrm{A}_{3} \mathrm{~S}_{2}$ (here the following abbreviations are used: $\mathrm{A}-$ $\mathrm{Al}_{2} \mathrm{O}_{3}, \mathrm{C}-\mathrm{CaO}, \mathrm{H}-\mathrm{H}_{2} \mathrm{O}, \mathrm{S}-\mathrm{SiO}_{2}$ ).

So we can state that during the calcinations of phosphogypsum and kaolin we can anticipate a number of interactions. Let us take a look at possible ones during which substances with various composition are formed.

1) Formation of calcium and aluminium silicates: $\mathrm{C} / \mathrm{K}=1$ :

$\mathrm{CaSO}_{4}+\left[\mathrm{Al}_{2} \mathrm{O}_{3} \cdot 2 \mathrm{SiO}_{2} \cdot 2 \mathrm{H}_{2} \mathrm{O}\right]=\left[\mathrm{CaO} \cdot \mathrm{SiO}_{2}\right]+$ $\left[\mathrm{Al}_{2} \mathrm{O}_{3} \cdot \mathrm{SiO}_{2}\right]+2 \mathrm{H}_{2} \mathrm{O}+\mathrm{SO}_{2}+0,5 \quad \mathrm{O}_{2}, T_{r}>891 \mathrm{~K}$

$\mathrm{C} / \mathrm{K}=1,33$ :

$4 \mathrm{CaSO}_{4}+3\left[\mathrm{Al}_{2} \mathrm{O}_{3} \cdot 2 \mathrm{SiO}_{2} \cdot 2 \mathrm{H}_{2} \mathrm{O}\right]=4\left[\mathrm{CaO} \cdot \mathrm{SiO}_{2}\right]+$

$\left[3 \mathrm{Al}_{2} \mathrm{O}_{3} \cdot 2 \mathrm{SiO}_{2}\right]+6 \mathrm{H}_{2} \mathrm{O}+4 \mathrm{SO}_{2}+2 \mathrm{O}_{2}, T_{r}>973 \mathrm{~K}$

$\mathrm{C} / \mathrm{K}=1,5$ :

$3 \mathrm{CaSO}_{4}+2\left[\mathrm{Al}_{2} \mathrm{O}_{3} \cdot 2 \mathrm{SiO}_{2} \cdot 2 \mathrm{H}_{2} \mathrm{O}\right]=\left[3 \mathrm{CaO} \cdot 2 \mathrm{SiO}_{2}\right]+$

$2\left[\mathrm{Al}_{2} \mathrm{O}_{3} \cdot \mathrm{SiO}_{2}\right]+4 \mathrm{H}_{2} \mathrm{O}+3 \mathrm{SO}_{2}+1,5 \mathrm{O}_{2}, T_{r}>1020 \mathrm{~K}$

$\mathrm{C} / \mathrm{K}=2$ :

$\left.2 \mathrm{CaSO}_{4}+\mathrm{Al}_{2} \mathrm{O}_{3} \cdot 2 \mathrm{SiO}_{2} \cdot 2 \mathrm{H}_{2} \mathrm{O}\right]=\left[2 \mathrm{CaO} \cdot \mathrm{SiO}_{2}\right]+$ $\left[\mathrm{Al}_{2} \mathrm{O}_{3} \cdot \mathrm{SiO}_{2}\right]+2 \mathrm{H}_{2} \mathrm{O}+2 \mathrm{SO}_{2}+\mathrm{O}_{2}, T_{r}>1126 \mathrm{~K}$ 
$\mathrm{C} / \mathrm{K}=2,5$ :

$5 \mathrm{CaSO}_{4}+2\left[\mathrm{Al}_{2} \mathrm{O}_{3} \cdot 2 \mathrm{SiO}_{2}-2 \mathrm{H}_{2} \mathrm{O}\right]=\left[3 \mathrm{CaO} \cdot \mathrm{SiO}_{2}\right]+$

$\left[2 \mathrm{CaO} \cdot \mathrm{SiO}_{2}\right]+2\left[\mathrm{Al}_{2} \mathrm{O}_{3} \cdot \mathrm{SiO}_{2}\right]+4 \mathrm{H}_{2} \mathrm{O}+5 \mathrm{SO}_{2}+$

$2,5 \mathrm{O}_{2}, T_{r}>1220 \mathrm{~K}$

$\mathrm{C} / \mathrm{K}=3$ :

$3 \mathrm{CaSO}_{4}+\left[\mathrm{Al}_{2} \mathrm{O}_{3} \cdot 2 \mathrm{SiO}_{2} \cdot 2 \mathrm{H}_{2} \mathrm{O}\right]=\left[3 \mathrm{CaO} \cdot \mathrm{SiO}_{2}\right]+$

$\left[\mathrm{Al}_{2} \mathrm{O}_{3} \cdot \mathrm{SiO}_{2}\right]+2 \mathrm{H}_{2} \mathrm{O}+3 \mathrm{SO}_{2}+1,5 \mathrm{O}_{2}, T_{r}>1291 \mathrm{~K}$

2) Formation of calcium alumosilicates

$\mathrm{C} / \mathrm{K}=1$ (anorthite):

$\mathrm{CaSO}_{4}+\left[\mathrm{Al}_{2} \mathrm{O}_{3} \cdot 2 \mathrm{SiO}_{2} \cdot 2 \mathrm{H}_{2} \mathrm{O}\right]=\left[\mathrm{CaO} \cdot \mathrm{Al}_{2} \mathrm{O}_{3} \cdot 2 \mathrm{SiO}_{2}\right]+$ $2 \mathrm{H}_{2} \mathrm{O}+\mathrm{SO}_{2}+0,5 \mathrm{O}_{2}, T_{r}>816 \mathrm{~K}$

$\mathrm{C} / \mathrm{K}=2$ (helenite):

$2 \mathrm{CaSO}_{4}+\left[\mathrm{Al}_{2} \mathrm{O}_{3}-2 \mathrm{SiO}_{2}-\right.$

$\left.2 \mathrm{H}_{2} \mathrm{O}\right]=\left[2 \mathrm{CaO} \cdot \mathrm{Al}_{2} \mathrm{O}_{3} \cdot \mathrm{SiO}_{2}\right]+$

$\mathrm{SiO}_{2}+2 \mathrm{H}_{2} \mathrm{O}+2 \mathrm{SO}_{2}+\mathrm{O}_{2}, T_{r}>1060 \mathrm{~K}$

$\mathrm{C} / \mathrm{K}=3$ (helenite):

$3 \mathrm{CaSO}_{4}+\left[\mathrm{Al}_{2} \mathrm{O}_{3} \cdot 2 \mathrm{SiO}_{2} \cdot 2 \mathrm{H}_{2} \mathrm{O}\right]=\left[2 \mathrm{CaO} \cdot \mathrm{Al}_{2} \mathrm{O}_{3} \cdot \mathrm{SiO}_{2}\right]+$

$\left[\mathrm{CaSO}_{4} \cdot \mathrm{SiO}_{2}\right]+2 \mathrm{H}_{2} \mathrm{O}+3 \mathrm{SO}_{2}+1,5 \mathrm{O}_{2}, T_{r}>1060 \mathrm{~K}$

$\mathrm{C} / \mathrm{K}=3,5$ (grossularite):

$7 \mathrm{CaSO}_{4}+2\left[\mathrm{Al}_{2} \mathrm{O}_{3} \cdot 2 \mathrm{SiO}_{2} \cdot 2 \mathrm{H}_{2} \mathrm{O}\right]=\left[3 \mathrm{CaO} \cdot \mathrm{Al}_{2} \mathrm{O}_{3} \cdot 3 \mathrm{SiO}_{2}\right]+$

$\left[3 \mathrm{CaSO}_{4} \cdot \mathrm{SiO}_{2}\right]+\left[\mathrm{CaO} \cdot \mathrm{Al}_{2} \mathrm{O}_{3}\right]+4 \mathrm{H}_{2} \mathrm{O}+7 \mathrm{SO}_{2}+3,5 \mathrm{O}_{2}$, $T_{r}>1275 \mathrm{~K}$

3) Calcium silicate and alumosilicate formation

$\mathrm{C} / \mathrm{K}=4$ :

$8 \mathrm{CaSO}_{4}+2\left[\mathrm{Al}_{2} \mathrm{O}_{3} \cdot 2 \mathrm{SiO}_{2} \cdot 2 \mathrm{H}_{2} \mathrm{O}\right]=2\left[3 \mathrm{CaO} \cdot 2 \mathrm{SiO}_{2}\right]+$

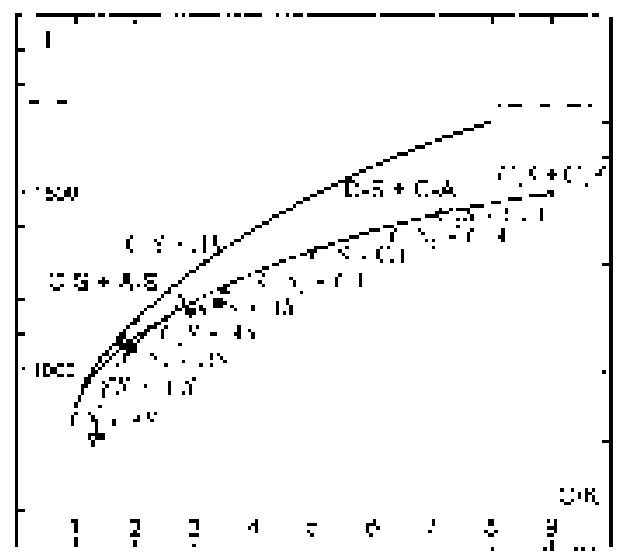

Fig 2. Dependence of the temperature of phosphogypsumkaolin high-temperature interaction on a molar gypsumkaolin ratio $\mathrm{C} / \mathrm{K}$. The dash line represents the breakdown temperature of pure gypsum. Numbers $1-\mathrm{CAS}_{2} 2 ; 3-$ $\mathrm{C}_{2} \mathrm{AS} ; 4-\mathrm{C}_{3} \mathrm{AS}_{3}$
$2\left[\mathrm{CaO} \cdot \mathrm{Al}_{2} \mathrm{O}_{3}\right]+4 \mathrm{H}_{2} \mathrm{O}+8 \mathrm{SO}_{2}+4 \mathrm{O}_{2}, T_{r}>1275 \mathrm{~K}$

$\mathrm{C} / \mathrm{K}=5$ :

$\left.5 \mathrm{CaSO}_{4}+\mathrm{Al}_{2} \mathrm{O}_{3} \cdot 2 \mathrm{SiO}_{2} \cdot 2 \mathrm{H}_{2} \mathrm{O}\right]=2\left[2 \mathrm{CaO} \cdot \mathrm{SiO}_{2}\right]+$

$\left[\mathrm{CaO} \cdot \mathrm{Al}_{2} \mathrm{O}_{3}\right]+2 \mathrm{H}_{2} \mathrm{O}+5 \mathrm{SO}_{2}+2,5 \mathrm{O}_{2}, T_{r}>1340 \mathrm{~K}$

$\mathrm{C} / \mathrm{K}=6$ :

$6 \mathrm{CaSO}_{4}+\left[\mathrm{Al}_{2} \mathrm{O}_{3} \cdot 2 \mathrm{SiO}_{2} \cdot 2 \mathrm{H}_{2} \mathrm{O}\right]=\left[3 \mathrm{CaO} \cdot 2 \mathrm{SiO}_{2}\right]+$

$\left[3 \mathrm{CaO} \cdot \mathrm{Al}_{2} \mathrm{O}_{3}\right]+2 \mathrm{H}_{2} \mathrm{O}+6 \mathrm{SO}_{2}+3 \mathrm{O}_{2}, T_{r}>1410 \mathrm{~K}$

$\mathrm{C} / \mathrm{K}=7$ :

$7 \mathrm{CaSO}_{4}+\left[\mathrm{Al}_{2} \mathrm{O}_{3} \cdot 2 \mathrm{SiO}_{2} \cdot 2 \mathrm{H}_{2} \mathrm{O}\right]=2\left[2 \mathrm{CaO} \cdot \mathrm{SiO}_{2}\right]+$

$\left[3 \mathrm{CaO} \cdot \mathrm{Al}_{2} \mathrm{O}_{3}\right]+2 \mathrm{H}_{2} \mathrm{O}+7 \mathrm{SO}_{2}+3,5 \mathrm{O}_{2}, T_{r}>1443 \mathrm{~K}$

$\mathrm{C} / \mathrm{K}=9$ :

$9 \mathrm{CaSO}_{4}+\left[\mathrm{Al}_{2} \mathrm{O}_{3} \cdot 2 \mathrm{SiO}_{2} \cdot 2 \mathrm{H}_{2} \mathrm{O}\right]=2\left[3 \mathrm{CaO} \cdot \mathrm{SiO}_{2}\right]+$

$\left[3 \mathrm{CaO} \cdot \mathrm{Al}_{2} \mathrm{O}_{3}\right]+2 \mathrm{H}_{2} \mathrm{O}+9 \mathrm{SO}_{2}+4,5 \mathrm{O}_{2}, T_{r}>1513 \mathrm{~K}$

\subsection{Discussion of results and experiments}

The calculated temperature $T_{r}$ of phosphogypsumkaolin interaction, $\mathrm{K}$ dependency on phosphogypsum and kaolin mole ratio $\mathrm{C} / \mathrm{K}$ are given in Fig 2. As it can be seen the interaction temperature depends on the ratio $\mathrm{C} /$ $\mathrm{K}$ : the higher the ratio, i e the more $\mathrm{CaO}$ moles take part is the reaction, the higher is the process temperature. This law of nature can be expressed by two curves the first one of which represents $\mathrm{C}-\mathrm{S}+\mathrm{A}-\mathrm{S}$, and the second one $-\mathrm{C}-\mathrm{S}+\mathrm{C}-\mathrm{A}$ systems. The three $\mathrm{C}-\mathrm{A}-\mathrm{S}$ system compounds anorthite $\mathrm{CaS}_{2}(1)$, helenite $\mathrm{C}_{2} \mathrm{AS}(2,3)$, grossularite $\mathrm{C}_{3} \mathrm{AS}_{3}$ (4) dots are close to the two curves. The system row is ended by the pure gypsum decomposition reaction (system 1). As we can see from the calculation results, $\mathrm{C}_{2} \mathrm{~S}$ is formed during the $(4,5,12,14)$ equation cases, at initial reaction temperatures $>(1126-1443) \mathrm{K}$, i e $>(853-1170){ }^{\circ} \mathrm{C}$. The probability of $\mathrm{C}_{2} \mathrm{~S}$ formation process from phosphogypsum and kaolin mixtures heated up to $120{ }^{\circ} \mathrm{C}$ can be arranged as follows: (4) $>(5)>$ (12) $>(14)$.

The following mixtures were heated: 1) phosphogypsum-kaolin (ratio 1:1; duration $5 \mathrm{~h}$; temperatures $\left.\left.500,700,800,900,1000,1200^{\circ} \mathrm{C}\right), 2\right)$ phosphogypsumkaolin (ratio $1: 1 ; 2: 1 ; 3: 1$; duration $30 \mathrm{~h}$; temperature $1200^{\circ} \mathrm{C}$ ).

As can be seen from the X-ray diffraction pattern analysis of heated phosphogypsum and kaolin mixtures in the temperature range $500-1200{ }^{\circ} \mathrm{C}$, the main compounds formed do not depend on the component proportions (1:1-3:1 interval) and on heating duration of 5 and $30 \mathrm{~h}$. The main substances formed are:

1) incomplete calcination residue - anhydrite,

2) anorthite formed at higher than $816 \mathrm{~K}\left(543{ }^{\circ} \mathrm{C}\right)$ 
temperatures according to reaction (7) (in Fig 2 its dot is in the lowest position),

3) cristobalite formed at higher than $1060 \mathrm{~K}\left(787^{\circ} \mathrm{C}\right)$ according to reaction (8),

4) mullite formed at higher than $1430 \mathrm{~K}\left(1157^{\circ} \mathrm{C}\right)$ temperatures,

5) $\mathrm{C}_{2} \mathrm{~S}$ formed at higher than $1126 \mathrm{~K}\left(853^{\circ} \mathrm{C}\right)$ according to reaction (4), higher than $1220 \mathrm{~K}\left(947^{\circ} \mathrm{C}\right)$ according to reaction (5) and higher than $1340 \mathrm{~K}$ $\left(1067{ }^{\circ} \mathrm{C}\right)$ according to reaction (12).

Different composition of calcium silicates formed during a high-temperature reaction of phosphogypsum and kaolin depends on the temperature: the higher the temperature, the greater is the $\mathrm{CaO} / \mathrm{SiO}_{2}$ molar ratio of the formed silicate. The main reason of this is that with an increase in basic oxide $\mathrm{CaO}$ incoming mole number, as can be seen from the above presented calculations, the lower is the negative standard Gibbs energy change for a mole of $\mathrm{CaO}$.

As a result of this, a higher temperature is needed for tricalcium silicate synthesis from gypsum and kaolin than for the case of dicalcium silicate (both compounds possess binding properties).

Calcium silicates, aluminates and alumosilicates (in all the 14 compounds) formation dependencies on gypsum and kaolin mixture heating temperature $t_{r k c},{ }^{\circ} \mathrm{C}$ and the compound composition can be expressed by the following additive equation:

$$
t_{r k c}=I_{C} \cdot C+I_{A} \cdot A+I_{S} \cdot S
$$

where $I_{C}, I_{A}, I_{s}-\mathrm{CaO}, \mathrm{Al}_{2} \mathrm{O}_{3}$ and $\mathrm{SiO}_{2}$ increments; $C$, $A, S-\mathrm{CaO}, \mathrm{Al}_{2} \mathrm{O}_{3}$ and $\mathrm{SiO}_{2} ; \%$ in the corresponding compound formula.

The solution of the 14 compound reaction equations according to the least square method allows us to obtain the following:

$$
t_{r k c}=8,14 \cdot C+3,912 \cdot A+2,849 \cdot S
$$

The correlation coefficient of calculated values and values obtained from the above equation is 0,9346 . This number $F$ is a criterion showing that a corresponding hypothesis can be accepted at $5 \%$ importance level and not rejected at $1 \%$ level.

So the heating of phosphogypsum with kaolin can give us dicalcium and tricalcium silicate possessing binding properties.

The following compound peaks were registered by $\mathrm{X}$-ray diffraction pattern analysis during heating phosphogypsum and kaolin mixtures at $(500-1200){ }^{\circ} \mathrm{C}$ : phosphogypsum decomposition product - anhydrite; kaolinite decomposition products - quartz; cristobalite $\mathrm{SiO}_{2}$ and mullite $\mathrm{A}_{3} \mathrm{~S}_{2}$; anhydrite and kaolinite interaction products - anorthite $\mathrm{CAS}_{2}$, helenite (melilite) $\mathrm{C}_{2} \mathrm{AS}$ and belite $\mathrm{C}_{2} \mathrm{~S}$; various admixtures present in the raw materials feldspar and mica.

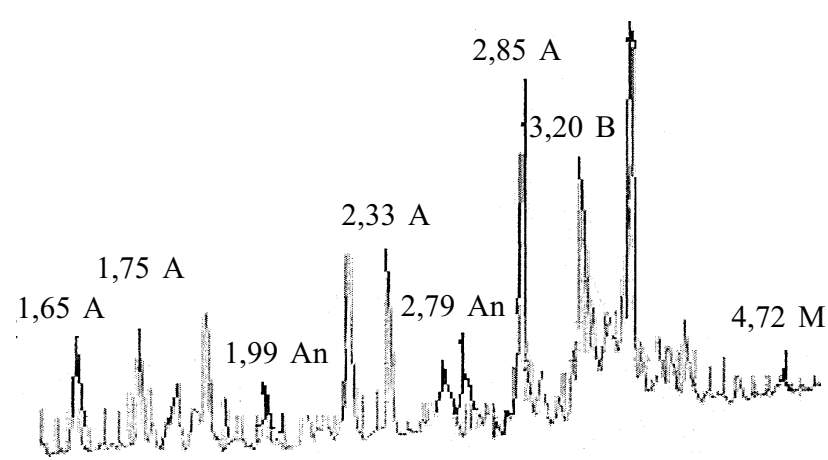

Fig 3. X-ray diffraction pattern of a phosphogypsum and kaolin mixture $(2: 1)$ heated at $1200{ }^{\circ} \mathrm{C}$ for $6 \mathrm{~h}$. Note: An anothite, $\mathrm{A}$ - anhydrite, $\mathrm{B}$ - belite, $\mathrm{M}$ - helenite (melilite)

A roentgenogram of a phosphogypsum and kaolin mixture $(2: 1)$, heated for $6 \mathrm{~h}$ at $1200^{\circ} \mathrm{C}$ is given in Fig 3. Here we can see that anhydrite predominates, and belite is also present. However, for the formation of a more significant amount of alite, it seems that higher temperatures are required.

Specimens were formed from the obtained materials and their compressive strength was determined. The results were 7,2 $\mathrm{MPa}$ (in the case of ordinary structural gypsum the value reaches only $7 \mathrm{MPa}$, while for a highquality structural gypsum - (15-20) $\mathrm{MPa}$. So we can interpret the product results as that for a low-strength binding material. If we wish to obtain higher strengths, we need to heat the mixtures at higher temperatures.

\section{Conclusions}

1.Anhydrite binding materials containing $\mathrm{CaO}$ as binding activator can be obtained from natural gypsum, anhydrite or phosphogypsum and kaolin, by heating these raw materials at higher than $1200{ }^{\circ} \mathrm{C}$ temperatures. An exact heating temperature for obtaining an expected amount of $\mathrm{CaO}$ in the product can be calculated according to the given thermodynamic equation.

2. Various calcium silicates as well as aluminates, alumosilicates and calcium alumosilicates, including materials with binding properties possessing like $\mathrm{C}_{2} \mathrm{~S}$ and $\mathrm{C}_{3} \mathrm{~S}$, can be obtained from a high-temperature $\left(\geq 1200^{\circ} \mathrm{C}\right)$ reaction of gypsum, anhydrite, phosphogypsum and kaolin interaction. The formation temperatures of these compounds can be calculated by using a linear additive equation. The obtained reaction products possess relatively low mechanical strength so the process should be conducted at higher than $1200{ }^{\circ} \mathrm{C}$ temperatures to obtain articles of a good quality.

3. The utilization of phosphogypsum could not only help to obtain structural materials from harmful production by-products, but also to decrease pollution arising from phosphogypsum waste into the atmosphere, wastewaters from leachates and soil by toxic hydrogen fluoride and other amounts of hazardous materials. The phosphogypsum utilization process can significantly improve the solution of environmental problems caused by the region's industry. 


\section{References}

1. Budukevičiūtè, L.; Kučinskienè, L. Investigation and application of methods for purifying the air polluted with phenol and formaldehyde. Environmental Engineering (Aplinkos inžinerija), Vol III, No 2(4). Vilnius: Technika, 1995, p 49-55 (in Lithuanian).

2. Kavolèlis, B.; Sirvydas, P. Prediction of ammonia concentration in cattle - houses. Environmental Engineering (Aplinkos inžinerija), Vol VII, No 3. Vilnius: Technika, 1999, p 114-117 (in Lithuanian).

3. Jakštaite, A.; Bakas, A.; Šimaitis, R. Biological air cleaning with activated sludge charge. Environmental Engineering (Aplinkos inžinerija), Vol VII, No 3. Vilnius: Technika, 1999, p 118-123 (in Lithuanian).

4. Paliulis, D.; Vasarevičius, S.; Baltrènas, P. Investigation of ceolite adsorptive layer aerodynamic resistance and filtration velocity. Environmental Engineering (Aplinkos inžinerija), Vol VII, No 4. Vilnius: Technika, 1999, p 212 216 (in Lithuanian).

5. Baltrènas, P.; Paliulis, D. Investigation of static and dynamic sulphur dioxide adsorption using natural ceolite modified with sodium carbonate solution. Environmental Engineering (Aplinkos inžinerija), Vol VIII, No 3. Vilnius: Technika, 2000, p 121-127 (in Lithuanian).

6. Spetylaitè, S.; Girgždys, A.; Baltrènas, P. Air pollution by carbon monoxide caused by motor transport on Vilnius streets. Journal of Environmental Engineering and Landscape Management, Vol XI, Suppl 2. Vilnius: Technika, 2003, p 33-39 (in Lithuanian).

7. Baltrènas, P.; Vaitiekūnas, P.; Mincevič, I. Investigation on the impact of transport exhaust emission to the air. Journal of Environmental Engineering and Landscape Management, Vol XII, No 1. Vilnius: Technika, 2004, p 3-11.

8. Zigmontienè, A.; Baltrènas, P. Biological purification of air polluted with volatile organic compounds by using active sludge recirculation. Journal of Environmental Engineering and Landscape Management, Vol XII, No 2. Vilnius: Technika, 2004, p 45-52.

9. Jasinevičienè, D.; Šopauskienè, D. Time trends of sulphate concentrations in atmospheric precipitation in Lithuania. Environmental Engineering (Aplinkos inžinerija), Vol VII, No 4. Vilnius: Technika, 1999, p 187-193 (in Lithuanian).

10. Damulevičius, V.; Ramonas, $\breve{C}$.; Ruplys, B. Drainage and treatment of polluted groundwater in the Jonava "Achema" enterprise territory. Environmental Engineering (Aplinkos inžinerija), Vol III, No 2(4). Vilnius: Technika, 1995, p 3337 (in Lithuanian).

11. Baltrènas, P.; Idzelis, R.; Petraitis, E. Investigation and evaluation of orimulsion dispersion in soil. Environmental Engineering (Aplinkos inžinerija), Vol VII, No 2, Vilnius: Technika, 1999, p 49-53 (in Lithuanian).

12. Kaminskas, A.; Smolianskienè, G.; Misiūnas, P. Application of magnesium oxide desulphurization of liquid fuel for reducing atmosphere pollution. Environmental Engineering (Aplinkos inžinerija), Vol VII, No 2. Vilnius: Technika, 1999, p 91-98 (in Lithuanian).

13. Baltrènas, P.; Bakas, A; Ignatavičius, G. Some aspects of investgating pollution sources in Vilnius well field secondary protections zones and estimating total organic car- bon concentracion. Environmental Engineering (Aplinkos inžinerija), Vol VIII, No 1. Vilnius: Technika, 2000, p 814 (in Lithuanian).

14. Dauknys, R.; Matuzevičius, A. Consumption of readily biodegradable organic matter and influence of nitrates on biological phosphorus removal from wastewater in Vilnius. Environmental Engineering (Aplinkos inžinerija), Vol IX, No 2. Vilnius: Technika, 2001, p 85-93 (in Lithuanian).

15. Idzelis, R.; Patašius, Ž. Investigation of oil product pollution in the ponds alongside the railway. Journal of Environmental Engineering and Landscape Management, Vol XI, Suppl 2. Vilnius: Technika, 2003, p 40-47 (in Lithuanian).

16. Bakas, A.; Kaulakys, J. A spring electrostatic precipitator. Environmental Engineering (Aplinkos inžinerija), Vol III, No 1(3). Vilnius: Technika, 1995, p 58-65 (in Lithuanian).

17. Matuzevičius, A.; Dilba, A. Experience in using anaerobic reactors for treating highly polluted wastewater. Environmental Engineering (Aplinkos inžinerija), Vol. VII, No 4. Vilnius: Technika, 1999, p 200-206 (in Lithuanian).

18. Baltrènas, P.; Paliulis, D.; Šimaitis, R. Numerical modeling of transferring processes in adsorption filters. Environmental Engineering (Aplinkos inžinerija), Vol IX, No 2. Vilnius: Technika, 2001, p 77-84 (in Lithuanian).

19. Baltrènas, P.; Vaiškūnaitè, R. Biological air purification by using activated pine-bark charge. Environmental Engineering (Aplinkos inžinerija), Vol X, No 2. Vilnius: Technika, 2002, p 70-76.

20. Baltrėnas, P.; Špakauskas, V.; Vaiškūnaite, R. Experimental study and mathematical modeling of biofiltration of volatile organic compound mixtures by a biofilter. Journal of Environmental Engineering and Landscape Management, Vol X, No 3. Vilnius: Technika, 2003, p 87-92.

21. Vaiškūnaitè, R. Investigation and application of a biofilter with activated pine-bark charge for air purification. Summary of a doctoral dissertation. Vilnius: Technika, 2004, $32 \mathrm{p}$.

22. Kaminskas, A. Building materials (The strategy of energy expendure reduction in building materials industry) Vilnius: Termoizoliacija, 2000. 172 p (in Lithuanian).

23. Leškevičienè, V. The pilot manufacturing of anhydrite cement in AB „Palemono keramika“. Kaunas: ASI, 1997. $12 \mathrm{p}$ (in Lithuanian).

24. Česniene, J.; Stonys, S. Investigation of anhydrite binding materials produced by neutralizated phosphogypsum. In: Proceedings of International Conference „Building Materials“. Kaunas: Technologija, 1980, p 61-65 (in Lithuanian).

25. Andriušienè, J.; Palubeckienè, V. Anhidrite material by the phospogypsum. In: Proceedings of International Conference „Modern Building Materials, Structures and Techniques“. Vilnius: Technika, 1990, p 32-34 (in Lithuanian).

26. Kazragis, A; Sakalauskas, K.; Zalieckienè, E. pH-metrical investigation of the heating productes of neutralizated phosphogypsum. In: Proceedings of International Conference „Modern Building Materials, Structures and Techniques“. Vilnius: Technika, 1995, p 200-205 (in Lithuanian).

27. Kazragis, A.; Gailius, A; Valaityte, L. Thermodynamical determination of temperature for the process of production 
anhydrite binding materials containing a fixed amount of activator. In: Proceedings of International Conference „Modern Building Materials, Structures and Techniques“. Vilnius: Technika, 1997, p.118 - 125 (in Lithuanian).

28. Kazragis, A.; Valaitytè, L; Gailius, A.; Juknevičiūte, A. The chemical and thermal processing of phosphogypsum. In: Proceedings of International Conference „Modern Building Materials, Structures and Techniques“. Vilnius: Technika, 1999, p 153-157 (in Lithuanian).

29. Kazragis, A.; Valaitytè, L; Juknevičiūtè, A. Thermodynamics of high-temperature interaction between gypsum and kaolin. In: Proceedings of International Conference „Hightemperature silicate materials" Vilnius: Termoizoliacija, 1999, p 43-45 (in Lithuanian).

30. Kazragis, A.; Gailius, A.; Valaityte, L. Binders on the base of gypsum either phosphogypsum and kaolin. In: Ibausil. 14. Internationale Baustofftagung, 20-23 September 2000, Weimar, BRD. Tagungsbericht - Band I. p 0227-0230.

\section{AUKŠTATEMPERATŪRIS FOSFOGIPSO NUKENKSMINIMAS IR UTILIZAVIMAS}

\section{A. Kazragis}

\section{$\mathrm{S}$ a n tra $\mathrm{uk}$ a}

1. Anhidritinès rišamosios medžiagos, kurių sudètyje yra rišimosi aktyviklio $\mathrm{CaO}$, gali būti gaunamos iš gamtinio gipso, anhidrito arba fosfogipso ir kaolino, iškaitinant šias žaliavas aukštesnèse negu $1200{ }^{\circ} \mathrm{C}$ temperatūrose. Kaitinimo temperatūrą, būtiną norimam $\mathrm{CaO}$ kiekiui produkte gauti, galima apskaičiuoti, remiantis pateikiama termodinamine lygtimi.

2. Dèl aukštatemperatūrès $\left(\geq 1200^{\circ} \mathrm{C}\right)$ gipso, anhidrito arba fosfogipso ir kaolino sąveikos gali susidaryti kalcio silikatai bei aliuminatai, aliuminio silikatai ir kalcio aliumosilikatai, tarp ju ir medžiagos, tokios kaip $\mathrm{C}_{2} \mathrm{~S}$ bei $\mathrm{C}_{3} \mathrm{~S}$, kurioms būdingos rišamosios savybès. Šių junginių susidarymo temperatūros gali būti apskaičiuotos, taikant linijinę adityvinę lygtị. Gautiems reakcijos produktams būdinga nedidelis mechaninis stiprumas, todẻl gaminant dirbinius iš šių medžiagų, tikslinga, kad procesas vyktų aukštesnèse negu $1200{ }^{\circ} \mathrm{C}$ temperatūrose.

3. Fosfogipso utilizavimas ne tik padètų iš žalingu gamybos atliekų gauti statybines medžiagas, bet ir iki minimumo sumažètu iš fosfogipso terikonu i atmosferą, nutekamuosius vandenis bei gruntą patenkančių nuodingų fluoro vandenilio ir kitų kenksmingų medžiagu. Fosfogipso utilizavimo procesas padètu spręsti apsaugos problemas gamybos rajone.

Raktažodžiai: nukenksminimas, utilizavimas, fosfogipsas, kaolinas, aukštatemperatūris apdeginimas, rišamosios medžiagos.

\section{ВЫСОКОТЕМПЕРАТУРНОЕ ОБЕЗВРЕЖИВАНИЕ И УТИЛИЗАЦИЯ ФОСФОГИПСА}

\section{А. Казрагис}

P е 3 ю м е

Ангидритные вяжущие материалы, содержащие активатор схватывания $\mathrm{CaO}$, могут быть получены путем совместного обжига смеси, состоящей из природного гипса, ангидрита или фосфогипса и каолина, при температурах $\geq 1200{ }^{\circ} \mathrm{C}$. Температура, необходимая для получения определенной доли активатора в составе ангидрита, может быть определена с помощью предложенного термодинамического уравнения.

В результате высокотемпературного взаимодействия между гипсом, ангидритом или фосфогипсом и каолином могут образоваться силикаты, алюмосиликаты и алюмосиликаты кальция, в том числе и обладающие вяжущими свойствами $\mathrm{C}_{2} \mathrm{~S}$ и $\mathrm{C}_{3} \mathrm{~S}$. Температуры образования этих соединений могут быть вычислены с помощью линейного аддитивного уравнения. Полученные продукты обжига обладают невысокой механической прочностью, поэтому при производстве изделий из таких материалов целесообразно проводить обжиг при температурах, превышающих $1200{ }^{\circ} \mathrm{C}$.

Утилизация фосфогипса представляет собой возможность снизить до минимума концентрации попадающих из терриконов в атмосферу и грунтовые воды таких ядовитых веществ, как фтористый водород. Поэтому процесс утилизации фосфогипса должен положительно сказываться на процессе охраны окружающей среды в районе производства фосфогипса.

Ключевые слова: обезвреживание, утилизация, фосфогипс, каолин, высокотемпературный обжиг, вяжущие материалы. 